\title{
, \\ Delay Causes and Types in Nigerian Power Construction Projects
}

\author{
Usman Ismaila ${ }^{1}$, Wooyong Jung ${ }^{1, *}$ and Chan Young Park ${ }^{2, *}$ \\ 1 Department of Nuclear Power Plant Engineering, KEPCO International Nuclear Graduate School, \\ Ulsan 45014, Korea; cul_oma2478@yahoo.com \\ 2 Intelligent Construction Automation Center, Kyungpook National University, Daegu 41566, Korea \\ * Correspondence: wooyong@kings.ac.kr (W.J.); pcy3088@knu.ac.kr (C.Y.P.); \\ Tel.: +82-52-712-7120 (W.J.); +82-53-950-6283 (C.Y.P.)
}

check for

updates

Citation: Ismaila, U.; Jung, W.; Park,

C.Y. Delay Causes and Types in

Nigerian Power Construction

Projects. Energies 2022, 15, 814.

https://doi.org/10.3390/en15030814

Academic Editor: Nerija Banaitiene

Received: 24 September 2021

Accepted: 16 January 2022

Published: 23 January 2022

Publisher's Note: MDPI stays neutral with regard to jurisdictional claims in published maps and institutional affiliations.

Copyright: (C) 2022 by the authors. Licensee MDPI, Basel, Switzerland. This article is an open access article distributed under the terms and conditions of the Creative Commons Attribution (CC BY) license (https:// creativecommons.org/licenses/by/ $4.0 /)$.

\begin{abstract}
Numerous events cause delays to entire power projects' completion timelines, leading to loss. This paper focuses on revealing the critical delay causes in Nigerian power projects and identifying the delay types such as excusable delay, compensable delay, critical delay, and concurrent delay from the different perspectives of owner and contractor. Based on the survey of the 84 industrial experts in power distribution and transmission projects in Nigeria, this study provides the mean score and rank of 39 delay causes. Among the causes, 14 are identified as critical in the Nigerian power project. The top three critical delay causes are corruption and bureaucracy in government, inadequate fund/budget allocation, and price fluctuation/inflation. Owner and contractor do not show the difference in classifying the 14 delay causes into excusable and compensable delays. However, there was a difference between owner and contractor in categorizing whether a cause is critical or not and concurrent or not. A different viewpoint of types of delay cause can lead to a dispute which may lead to other delays and losses, and thus it is meaningful to understand the types of delay perceived from owner and contractor. Even though the delay cause and types are different depending on an individual project, the results of this study serve as a reference and would be beneficial for the practitioners in the construction industry to help identify the delay causes to manage them effectively.
\end{abstract}

Keywords: delay cause; delay types; excusable delay; compensable delay; critical delay; concurrent delay

\section{Introduction}

Delays can be considered analogous to risk, as most construction projects are exposed to delays. Delays in construction projects in various countries lead to losses on the part of owners and contractors [1]. In Nigeria, Ikechukwu and Emoh [2] stated that the trend of delay events in a construction project including power projects could lead to increased overall costs while also inordinately extending the project completion time by a high percentage. Gatugel Usman et al. [3] also claimed that in Nigeria, there is a prevailing circumstance in that the availability of funds is progressively dwindling, and creative and innovative solutions are pertinent to addressing the power supply problems, in which delays may prove an impediment.

Many previous studies have investigated the delay cause to achieve better project management performance [4-6]. However, each project has distinctive characteristics such as region, country, product, stakeholder, and thus each project is exposed to different aspects of delay cause and performance. It is important to understand which delay causes exist and how much they affect to performance for the successful implementation of the following Nigerian power project.

In addition, Trauner [7] claimed that in determining the impact of a project schedule delay, analyzing whether the delay type is excusable, compensable, critical, and concurrent is important. These delay types may also have been perceived differently by either the owners or contractors. It is important to exactly understand how the perception of delay type is different between the main players of the project, the owners and contractors. A 
different viewpoint of the type of delay cause can lead to a dispute which may cause other delays and losses. The responsibility of delay causes can be appropriately discussed and allocated by understanding the delay type perceived. It is worthy to note that most previous research did not investigate what kinds of delay causes are usually excusable, compensable, critical, or concurrent in construction projects.

Therefore, this study is done to close a gap in past research, by investigating the top delay cause in Nigerian power construction projects and investigating the delay types from the owner and contractor perspectives to effectively manage the delay performance of the project. The rest of the paper is divided as follows. Section 2 is a literature review of delay causes and types, which forms the theoretical background of the study. Section 3 shows the methodology employed in carrying out the research. Section 4 shows the results obtained, with a brief discussion. Finally, Section 5 provides the conclusions and limitations.

\section{Research Background}

\subsection{Causes of Delays}

Many researchers have investigated delays in construction projects to improve project management performance. Among them, this study selected the studies that are associated with Nigerian power projects. First, several studies have investigated the delay cause of power projects. Banobi and Jung [6] analyzed the delay of power projects from the perspectives of the owners and contractors for a successful project, identifying gaps between owners and contractors in Tanzania. Results showed that the owners and contractors identified similar causes of delay such as vandalism and long waits to obtain permits from authorities, change in scope, owner's poor supervision, failure in planning, and design error. Pall et al. [8] examined the unique delay cause factors in power transmission projects and revealed critical causes of delay to projects as external/unavoidable factors. Here, the top-ranked factors were the right of way problems for the transmission lines, frequent changes in transmission line routes, and accessibility to the transmission line tower amongst others.

Second, several studies have investigated the delay cause in developing countries. Nundwe and Mulenga [9] also revealed delay causes in Zambia power construction projects such as late advance payments, poor financial management by the contractor, and irregular payments to sub-contractors. Mahamid et al. [10] analyzed the time performance of road construction projects in the West Bank of Palestine and identified the five most severe delay causes as the political situation, segmentation of the West Bank, limited movement between areas, awarding of projects to lowest bidders, payment delays from the owner, and the shortage of equipment. Aziz and Abdel-Hakam [11] investigated the causes of road construction delays in Egypt and found the delay causes to be financial problems, shortages in equipment, construction materials and skilled operators, inexperienced workers, revisions, changes, or errors in design, delays in design submission, and soil and underground problems. Gebrehiwet and Luo [12], in a past study, investigated and discovered the unique causes of delays in Ethiopia's construction projects which are corruption, unavailability of utilities at the site, inflation/price increases in materials, lack of quality materials, late design and design documents, slow delivery of materials, unreasonably long lead-times in approving and receiving completed project work, poor site management and performance, late release of budget/funds, and ineffective project planning and scheduling. Bajjou and Chafi [13], in another study in Moroccan construction projects, revealed the top ten causes to be the delays in progress payments, lack of training for employees, lack of waste management strategy, unrealistic contract duration imposed by the client, revisions due to construction errors, excessive subcontracting, delays in obtaining permits from governmental agencies, ineffective planning and scheduling, the lack of collective planning, and the unskilled workforce. Rashid [14] also explored the causes of delay in construction projects executed in Pakistan and identified the significant causes as contractor-related factors, client-related factors, consultant-related factors, material-related factors, labor-related factors, and general-related factors. Sagarkumar [15] analyzed the 
delay causes in construction projects in India and revealed the major contributing factors to construction delay as lack of labor-management, excess workload, corruption, changes in laws, and shortages of equipment. Hossen et al. [16] found the most significant subfactors in a nuclear power plant construction schedule to be policy changes, political instability, regulatory and license issues, robust designs, document review procedures, redesign due to errors, shortage of qualified experienced nuclear equipment manufacturers. Idow and Tajudeen [17], in the Nigerian experience, found some predominant causes of delay to construction project delivery in Nigeria such as changes in drawing.

Based on the literature review of previous studies on delay causes and types in construction projects which cuts across Nigeria and some developing countries, this study identified 39 delay causes which formed the basis for investigating the Nigerian case, because most construction projects around these developing countries may share some similarity in delay cause (Table 1).

Table 1. Delay causes identified in previous studies.

\begin{tabular}{|c|c|c|c|}
\hline ID & Delay Causes & Description & References \\
\hline DC1 & Inadequate fund/budget allocation & $\begin{array}{l}\text { Delay due to inadequate funds and poor budgeting which leads to } \\
\text { ultimate delay of construction project }\end{array}$ & {$[10-12,17]$} \\
\hline DC2 & Poor communication & $\begin{array}{l}\text { Delay cause which is due to inability to communicate issues that goes to } \\
\text { the root of the contract between stakeholder }\end{array}$ & {$[7,13]$} \\
\hline DC3 & Delay in approving the changes & $\begin{array}{l}\text { Delay in approving the changes in design and other matters for the } \\
\text { project implementation }\end{array}$ & {$[7,11,14]$} \\
\hline DC4 & Unrealistic contract duration/type & $\begin{array}{l}\text { Delay results from the unrealistic period of completion of the project } \\
\text { to inexperience }\end{array}$ & {$[13,14]$} \\
\hline DC5 & Regulatory/license requirement & $\begin{array}{l}\text { Delay from an inability to meet regulatory license requirements for the } \\
\text { construction of nuclear power projects }\end{array}$ & {$[13,15,16]$} \\
\hline DC6 & Lack of experience of owner & $\begin{array}{l}\text { Delay from the inexperienced owner has a significant impact on } \\
\text { project performance }\end{array}$ & {$[9,13,16]$} \\
\hline DC7 & Delay in owner's procurement & $\begin{array}{l}\text { Delay from late procurement of owner supply construction material } \\
\text { and equipment, and delivery }\end{array}$ & {$[10,14]$} \\
\hline DC8 & Poor coordination/supervision & $\begin{array}{l}\text { Delay from poor supervisory functions like; allocation of work, } \\
\text { decisions, monitoring for compliance and providing leadership }\end{array}$ & [14] \\
\hline DC9 & Inappropriate project scope & $\begin{array}{l}\text { Delay due to unclear specification or contract including the } \\
\text { responsibilities of the parties, milestone and technicality of the project }\end{array}$ & {$[14,17,18]$} \\
\hline DC10 & Poor standard of drawing & $\begin{array}{l}\text { Delay from poor quality drawings which leads to reconstructions or } \\
\text { modification resulting from the errors }\end{array}$ & {$[14,17,19]$} \\
\hline DC11 & Inadequate review procedures & $\begin{array}{l}\text { Poor planning and management procedure definitions for construction } \\
\text { work to ensure quality }\end{array}$ & {$[11,12,16,17]$} \\
\hline $\mathrm{DC} 12$ & Incomplete design and estimate & $\begin{array}{l}\text { Delay due to incomplete fundamental to shape and form of } \\
\text { construction which can negatively influence project completion }\end{array}$ & {$[11,12,16,17]$} \\
\hline DC13 & Inappropriate data collection & $\begin{array}{l}\text { Delay due to inability to answer questions concerning the project, also } \\
\text { inability to validate results of certain changes leading to distorted } \\
\text { recommendations and decisions }\end{array}$ & {$[14,17]$} \\
\hline DC14 & Poor planning and scheduling & $\begin{array}{l}\text { Delay due to lack of planning leading to disorganized construction } \\
\text { work activities }\end{array}$ & {$[12,13]$} \\
\hline DC15 & Inadequate site supervision & $\begin{array}{l}\text { Delay from poor supervision practices, including poor planning } \\
\text { management of tools, equipment, material, and labor }\end{array}$ & {$[12,14]$} \\
\hline DC16 & Strikes by site personnel & Delay due to strikes by site worker & {$[7,14,19]$} \\
\hline DC17 & Poor construction materials & $\begin{array}{l}\text { Delay from use of poor quality of material and workmanship which } \\
\text { affects overall construction quality and performance }\end{array}$ & {$[12,19]$} \\
\hline
\end{tabular}


Table 1. Cont.

\begin{tabular}{|c|c|c|c|}
\hline ID & Delay Causes & Description & References \\
\hline DC18 & Price fluctuation/inflation & $\begin{array}{l}\text { Delay from economic volatility and the eventual increase in the prices } \\
\text { of construction material, equipment and labor }\end{array}$ & {$[12,20]$} \\
\hline DC19 & Poor cost control & $\begin{array}{l}\text { Delay from poor project estimate, design errors, administrative } \\
\text { mismanagement, and not hiring the right team }\end{array}$ & {$[9,12]$} \\
\hline DC20 & Late procurement orders & $\begin{array}{l}\text { Delay that can result from contractors' late procurement of construction } \\
\text { material and equipment }\end{array}$ & [9] \\
\hline DC21 & Lack of experience of contractor & $\begin{array}{l}\text { Delay from contractors' poor leadership and management because of } \\
\text { lack of skill in the line of work }\end{array}$ & [11] \\
\hline DC22 & Shortage of material in the market & $\begin{array}{l}\text { Delay due to shortage of material and problems due to increasing in the } \\
\text { cost of construction material }\end{array}$ & {$[12,21]$} \\
\hline DC23 & Shortage of equipment on site & $\begin{array}{l}\text { Delay due to inability to provide sufficient construction equipment to } \\
\text { site due low finances and improper budget provision }\end{array}$ & {$[10,11,15]$} \\
\hline DC24 & Shortage of power & Delay due to inadequate electric power supply outage to the site & {$[9,12]$} \\
\hline DC25 & High interest rates & $\begin{array}{l}\text { Delay due to increasing in interest rate results in an overall increase in } \\
\text { project cost }\end{array}$ & [14] \\
\hline DC26 & Poor working condition & $\begin{array}{l}\text { Delay due to poor environmental working conditions which affect the } \\
\text { morale of employees }\end{array}$ & {$[13,14]$} \\
\hline DC27 & Workers' absenteeism & $\begin{array}{l}\text { Delay due to employees' absence from work which goes a long way to } \\
\text { affecting productivity }\end{array}$ & [14] \\
\hline DC28 & Vandalism & $\begin{array}{l}\text { Delay from the destruction of construction arrangements like material } \\
\text { or equipment at the site }\end{array}$ & [6] \\
\hline DC29 & Kidnapping or terrorism & $\begin{array}{l}\text { Delay from abnormal behavior of persons towards the employee, } \\
\text { owners and contractors }\end{array}$ & [14] \\
\hline DC30 & Theft & Delay from theft of construction materials or equipment at the site & [14] \\
\hline DC31 & Conflicts with neighbor & $\begin{array}{l}\text { Delay from disputes with neighbors due to contradiction of interest of } \\
\text { each stakeholder through project implementation }\end{array}$ & {$[14,16]$} \\
\hline DC32 & Political Instability & $\begin{array}{l}\text { Delay from unforeseen political unrest or events by the government } \\
\text { or political }\end{array}$ & {$[8,10,16]$} \\
\hline DC33 & Government interference & $\begin{array}{l}\text { Delay from a political decision or pressure from the high-level } \\
\text { governance }\end{array}$ & {$[7,8]$} \\
\hline DC34 & Cost of material & $\begin{array}{l}\text { Delay due to unforeseen increase in the cost of material due to sudden } \\
\text { inflation rate in the economy }\end{array}$ & {$[8,12,17]$} \\
\hline DC35 & Economic instability & Delay from economic volatility of host country & [8] \\
\hline DC36 & Corruption and bureaucracy & $\begin{array}{l}\text { Delay from corrupt or sharp practices with the management of } \\
\text { the project }\end{array}$ & {$[19,20]$} \\
\hline DC37 & Natural disaster & Delay from natural source such as hurricane, typhoon and storm & {$[8,14,19]$} \\
\hline DC38 & Unexpected geological conditions & $\begin{array}{l}\text { Delay from unforeseen adverse sites or underground conditions } \\
\text { through investigation }\end{array}$ & {$[7,11,14]$} \\
\hline DC39 & Act of God & $\begin{array}{l}\text { Delay which is assumed to comprise merely natural } \\
\text { unforeseen situations }\end{array}$ & {$[7,14,19]$} \\
\hline
\end{tabular}

\subsection{Delay Types}

Delays often arise between contractors and owners of projects, leading to many problems, like liquidated damage or disagreements or litigation about contracts. Over the years, many authors have shared their different perspectives on delay types and the challenges faced by parties in contracts with definitions and analysis. One of the categorizations of delay type is that classifying the delay into four types: excusable delay, compensable delay, critical delay, and concurrent delay [7].

\subsubsection{Excusable or Non-Excusable Delays}

Hamzah et al. [22] classified delays as excusable and non-excusable delays. The nonexcusable delays are caused by the contractors or their suppliers, and this is no fault of the owner in a construction project. Therefore, the contractor is often not entitled to relief, 
either with money or time and must make up for the time lost by accelerating the work or compensating the owner in other ways. Similarly, Theodore also expressed that all delays are either excusable or non-excusable [7]. An excusable delay is a delay that is due to an unforeseeable event beyond the contractor's or the subcontractor's control: for example, delays resulting from general labor strikes fires, floods, acts of God, owner-directed changes, errors and omissions in the plans and specifications, differing site conditions or concealed conditions, severe weather, intervention by outside agencies, and a lack of action by government bodies.

\subsubsection{Compensable or Non-Compensable Delays}

According to Kasimu and Isah [19], non-compensable delays are caused by third parties or incidents beyond the control of both the owner and the contractor. Examples include acts of God, unusual weather, strikes, fires, acts of government in its sovereign capacity. In this case, the contractor is normally entitled to a time extension but no compensation for delayed damages. In contrast, compensable delays are caused by the owner or the owner's agents, for example, the late release of drawings from the owner's architect. This leads to a schedule extension and exposes the owner to a financial damage claim by the contractor; whereas Zaki et al. [23] asserted that the client has more control over compensable delays and can take some actions to prevent them.

\subsubsection{Critical or Non-Critical Delays}

Gajare et al. [24] expressed that critical delay caused schedule delay to the entire project completion or a milestone date by affecting critical activities, whereas non-critical delays are schedule delays that do not affect the project completion or a milestone date. Fakunle and Fashina [21] said that critical delays prevent the contractor from concluding the work on the scheduled timeline agreed upon in the construction contract.

\subsubsection{Concurrent or Non-Concurrent Delays}

Concurrent delays are delays that occur at the same time or close to the same time [25]. Typically, many factors delay a project in an overlapping manner, which is more complicated. This delay can be caused by both owners and contractors. Livengood [20] also supported the idea that concurrent delays are very complex, and experts find themselves in disputes over the implementation of schedules when concurrency issues are involved in delays, leading to confusion in expert judgments. Munvar et al. [18] claimed that a concurrent delay in a project's schedule is due to two or more independent delay events happening at the same time. The concurrent delay leads to difficulties in attributing the responsibility for these delays and in deciding the way they are to be dealt with, as they are complex and intertwined.

The previous studies defined the delay types and investigated the delay causes included in four types in general. However, there lacks research that identifies the types of delay cause in power projects and investigates the classification from the perspective of owner and contractor. It is important to understand the perceived delay type of the owner and contractor since their perception gap can be an impediment to effective delay management and lead to a dispute about the responsibility of delay which causes another delay.

\section{Methodology}

\subsection{Questionnaire Design and Data Collection}

The questionnaire is designed based on an exhaustive literature review and respondents' answer possibility. The questionnaire is structured into four sections: (a) general information about the respondents and their organizations; (b) characteristics of the respondents' experienced project; (c) intensity of delay cause based on the respondent's project; and (d) classification of delay types of top five delay cause based on the perspective of owner and contractor, as shown in Appendix A. 
In order to collect the sample data, an offline survey was conducted using one hundred and fifty questionnaires to solicit and obtain expert opinions on delay causes and types. Thus, the survey was distributed to Nigerian experts who have experienced the power distribution and power transmission projects. Eighty-four experts validly responded to the total questionnaire issued. That is a total of about $49 \%$ of experts experienced the power transmission project and 51\% of experts experienced power distribution projects. The offline survey process covered six weeks. The major challenge experienced in carrying out the survey was: (1) the slow response to the questionnaires due to the partial operations of stakeholder organizations as a result of the COVID-19 pandemic; (2) it is not of many difficulties for respondents to allocate weight to the 39 delay causes. However, it is of burden for the respondent to allocate weight to the top five delay types.

\subsection{Respondent Profile}

Table 2 presents the profile of respondents' affiliation. The profile shows that $42.9 \%$ of the respondents are owners, $35.7 \%$ are contractors, while the $21.4 \%$ remaining are representatives of such organizations as utility companies.

Table 2. Profile of respondents' affiliation.

\begin{tabular}{ccc}
\hline Affiliation & Number & Percentage \\
\hline Owner & 36 & 42.9 \\
Contractor & 30 & 35.7 \\
Others & 18 & 21.4 \\
Total & 84 & 100 \\
\hline
\end{tabular}

Additionally, Figure 1 reveals the job position of the respondent that about a quarter of the respondents were project managers (25\%), with the largest respondents (38\%) as project engineers, and others like technicians $(8 \%)$, site managers $(10 \%)$, consultants taking up a $12 \%$, while surveyors made up $7.0 \%$, which constituted the smallest percentage of the respondents.
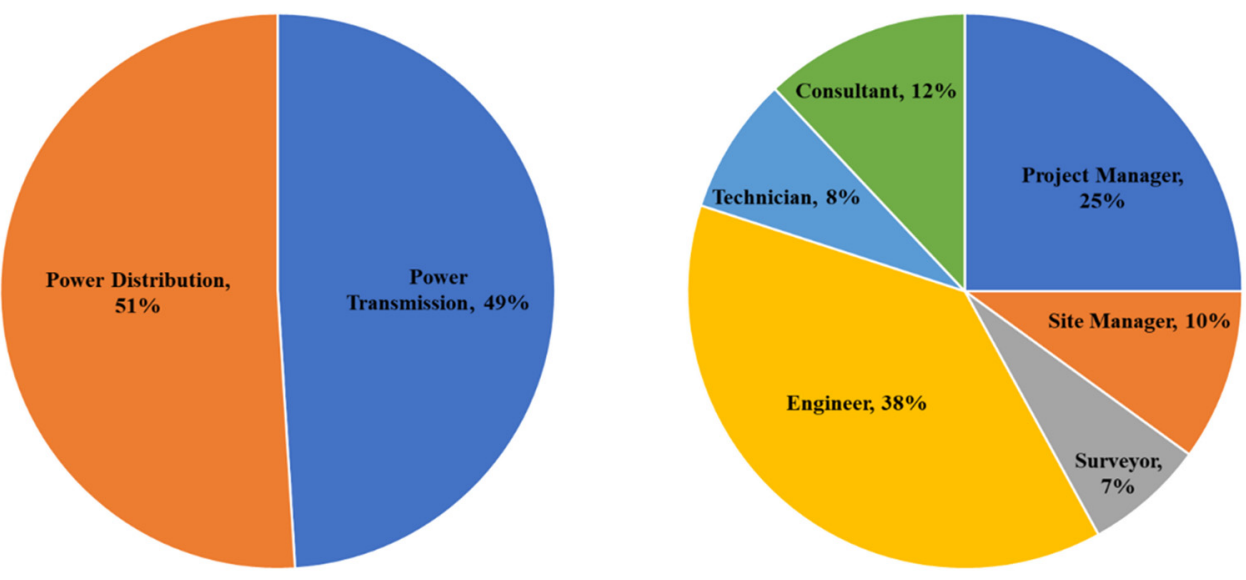

Figure 1. Sector and Job Position of Respondents.

\subsection{Data Analysis}

This study investigated the intensity of the delay causes. Thirty-nine delay causes were presented in a questionnaire and rated using the 7-Likert scale. This study provided the duration criteria of each scale when rating the importance as shown in Table 3 . Since each respondent has a different opinion of the criteria to each scale, the criteria can be effective to reduce the bias of each response. 
Table 3. Likert scale and duration criteria.

\begin{tabular}{ccc}
\hline Likert Scale & Intensity & Duration Criteria \\
\hline 1 & No Impact & N/A \\
2 & Very Low & Less than 1 Week \\
3 & Low & Less than 2 Week \\
4 & Slightly Low & Less than 1 Month \\
5 & Slightly High & Less than 3 Month \\
6 & High & Less than 6 Month \\
7 & Very High & More than 6 Month \\
\hline
\end{tabular}

The mean score ranking technique was used to rank the delay cause of Nigerian power projects. The perceived importance from the respondents acted as scores used to calculate the mean score for each factor and ranked according to the mean score.

One sample $t$-test is conducted to identify the critical delay cause of the Nigerian power project. The test value is 2 with a $95 \%$ confidence level. According to the duration criteria provided, delay causes whose mean score is higher than 2 are regarded as critical.

As for the analysis of delay type, the delay type of each cause is classified according to the percentage of the respondents who perceived that a delay cause is excusable or not, compensable or not, critical or not and concurrent or not.

\section{Results and Discussions}

\subsection{Critical Delay Causes in Nigerian Power Project}

In this study, Table 4 below presents the rank, mean and standard deviation of the delay cause factors in the Nigerian power project. The delay causes are sorted by rank in ascending order. The result of one sample $t$-test (test value $=2$, confidence level $=95 \%$ ) indicated that 14 delay causes are significantly important in the Nigerian power project. Twenty-five delay causes remaining is regarded as of significantly low importance because the mean value of these has not exceeded 2 . The critical delay causes are discussed below.

The corruption and bureaucracy in the Nigerian government which is an external factor to the owner and contractor ranks first (1st) amongst the delay cause factor and negatively affects the schedule of the Nigerian power projects with a mean score of 4.77. Similarly, studies for developing countries such as [12] in Ethiopia, [15] in India, also confirm that corruption is a dominant impediment to the timely completion of civil construction projects.

The inadequate funds and budget allocations (mean score: 4.71 ) is the 2nd ranked delay cause which also negatively affects the construction of the Nigeria power project. Here, the owner is impacted when inadequate funds and the budget are involved. In the same vein, studies by [9] in Zambia, [11] in Egypt, and [17] in Nigeria, also confirm that poor financial management problems and difficulty contributes to the delay in the scheduled completion of power distribution and other civil construction projects.

When price fluctuation and inflation (DC18, mean score: 4.23) are involved, this gives the 3rd ranked delay cause of the scheduled completion of power projects in Nigeria. This may have arisen as a result of the unstable economy in Nigeria. This delay cause is also seen in [12], confirming that inflation and price increase in a material is a contributor to the delay in the completion of construction projects.

With regulatory and license requirement (DC5), the 4th ranked delay cause with a mean score of 4.05 , the delay cause is seen to have also contributed to the scheduled delay cause in the timely completion of a power project in Nigeria. This delay may arise from the owner's inability to meet regulatory and license requirements or permits by the government to start the project work. Similarly, Hossen et al. [16] also confirm that the regulatory criteria and licensing documents conflicting with existing regulations also contribute to the ultimate delay of schedule completion of nuclear power plant projects.

Economic instability (DC35) ranks 5th among the identified causes of delay in Nigerian power projects, and it also contributes an approximate mean score of 3.75 that negatively 
affects the schedule completion of the Nigerian power project. This delay cause may have arisen from the unstable state of Nigeria's economy. Likewise, a previous study by Hossen et al. [16] also buttressed the fact that the economic instability of a country due to inflation and other factors can contribute to the ultimate delay of the scheduled completion of nuclear power and civil construction projects, respectively.

Design changes and the delay in approving changes (DC3), which ranks 6th in the overall delay cause in the scheduled completion of the Nigeria power project, has a mean score of 3.70. Here, the owner who is responsible for the design in the power project is impacted by delay either as a result of slow approval of design or changes. More so, government interference (DC33) ranks seventh and has a mean score of 3.48. It can be seen to equally have contributed delays to some projects in the past. For example, studies by Hossen et al. [16] also confirm this fact, that government interference plays a big role in the delay of the scheduled completion of nuclear power plant construction projects. In addition, lack of cost monitoring planning/poor cost control (DC19) ranks 8th with a mean score of 3.23. This delay cause was perceived to have contributed due to poor cost control by the contractors in the power projects. Inappropriate project scope (DC9) ranks as the 9th delay cause to the overall scheduled completion of the power project in Nigeria with a mean score of 3.13. A previous study in [14] confirmed that DC9 also contributes to the ultimate delay in construction projects. The cost of the material comes 10th in the delay cause to the timely completion of the Nigerian power project.

To sum up, corruption and bureaucracy in government (DC36), economic instability (DC35), inadequate fund/budget allocation (DC1) are frequently high ranked in a developing country such as not only Nigeria and but also Ethiopia and India. Therefore, the owner and government must first try to improve the delay causes by putting adequate measures to curb corruption, stabilize the economy, and provide financial supports to power construction companies. In addition, lack of cost and monitoring planning: poor cost control (DC19) and late procurement orders of material/equipment (DC20) also ranked high. Contractors should improve the related capability to reduce project delays.

Table 4. Rank and mean score of delay causes.

\begin{tabular}{|c|c|c|c|c|c|}
\hline ID & Delay Cause & Rank & Mean & Std. & $p$-Value \\
\hline DC36 & Corruption and bureaucracy in government & 1 & 4.77 & 2.22 & $0.000 *$ \\
\hline DC1 & Inadequate fund/budget allocation & 2 & 4.71 & 1.68 & $0.000 *$ \\
\hline DC18 & Price fluctuation/inflation & 3 & 4.23 & 1.81 & 0.000 * \\
\hline DC5 & Regulatory/license requirement & 4 & 4.05 & 1.83 & 0.000 * \\
\hline DC35 & Economic instability & 5 & 3.75 & 2.15 & 0.000 * \\
\hline DC3 & Design changes and delay in approving the changes & 6 & 3.70 & 1.90 & 0.000 * \\
\hline DC33 & Government interference & 7 & 3.48 & 2.09 & 0.000 * \\
\hline DC19 & Lack of cost and monitoring planning: poor cost control & 8 & 3.23 & 1.91 & $0.000 *$ \\
\hline DC9 & Inappropriate project scope & 9 & 3.13 & 2.15 & $0.000 *$ \\
\hline DC34 & Cost of material & 10 & 2.90 & 1.78 & 0.000 * \\
\hline DC14 & Poor Project planning and scheduling & 11 & 2.73 & 1.65 & 0.000 * \\
\hline DC2 & Poor communication & 12 & 2.55 & 1.65 & $0.006^{*}$ \\
\hline DC20 & Late procurement orders of material/equipment & 13 & 2.45 & 1.68 & 0.025 * \\
\hline DC32 & Political Instability & 14 & 2.42 & 1.67 & 0.033 * \\
\hline DC30 & Theft & 15 & 2.29 & 1.50 & 0.096 \\
\hline DC28 & Vandalism & 16 & 2.25 & 1.71 & 0.244 \\
\hline DC25 & High interest rates on the mode of financing & 17 & 2.21 & 1.36 & 0.215 \\
\hline DC13 & Inappropriate data collection & 18 & 2.17 & 1.48 & 0.315 \\
\hline DC12 & Incomplete design and estimate at the time of tender & 19 & 1.91 & 1.08 & 0.501 \\
\hline DC6 & Lack of experience of owner & 20 & 1.83 & 1.19 & 0.219 \\
\hline
\end{tabular}


Table 4. Cont.

\begin{tabular}{|c|c|c|c|c|c|}
\hline ID & Delay Cause & Rank & Mean & Std. & $p$-Value \\
\hline DC17 & Poor construction materials & 21 & 1.78 & 1.31 & 0.184 \\
\hline DC8 & Poor management: coordination/supervision & 22 & 1.77 & 0.97 & 0.055 \\
\hline DC24 & Shortage of power & 22 & 1.77 & 1.08 & 0.084 \\
\hline DC39 & Act of God & 24 & 1.77 & 1.39 & 0.162 \\
\hline DC7 & Delay in owner's procurement & 25 & 1.77 & 1.23 & 0.113 \\
\hline DC11 & Inadequate design document review procedures & 26 & 1.76 & 0.90 & 0.023 \\
\hline DC10 & Poor standard of drawing & 27 & 1.70 & 1.20 & 0.037 \\
\hline DC15 & Inadequate site supervision & 28 & 1.69 & 1.17 & 0.028 \\
\hline DC29 & Kidnapping or terrorism & 29 & 1.65 & 1.11 & 0.015 \\
\hline DC27 & Worker's absenteeism & 30 & 1.61 & 1.18 & 0.007 \\
\hline DC4 & Unrealistic contract duration/type & 31 & 1.60 & 1.20 & 0.007 \\
\hline DC21 & Lack of experience of contractor & 32 & 1.58 & 1.25 & 0.006 \\
\hline DC38 & Unexpected geological conditions & 33 & 1.57 & 1.15 & 0.003 \\
\hline DC23 & Equipment and tool shortage on site & 34 & 1.56 & 1.07 & 0.001 \\
\hline DC31 & Conflicts with neighbor & 34 & 1.56 & 1.00 & 0.000 \\
\hline DC22 & Shortage of material in the market & 36 & 1.51 & 0.93 & 0.000 \\
\hline DC37 & Natural disaster & 37 & 1.44 & 1.21 & 0.001 \\
\hline DC16 & Strikes by site personnel & 38 & 1.40 & 0.89 & 0.000 \\
\hline DC26 & Poor site working condition & 39 & 1.38 & 0.73 & 0.000 \\
\hline
\end{tabular}

$*$ : $p$-value $<0.05$ which refers to statistically significant.

\subsection{Types of Delay Cause in Nigerian Power Project}

This study investigated and classified the 14 critical delay causes into four types (excusable, compensable, critical, and concurrent delay) depending on the perspective of the owner and contractor. Delay causes were classified according to the experts' responses. For example, DC1: each owner was required to select if the DC1 is excusable, non-excusable, or I don't know (IDK), and since the percentage of excusable is large, DC1 is classified as an excusable delay from the owner's perspective. Since no responses were collected about DC20 from the contractors, DC20 is excluded in the contractor column of the table. Table 5 shows the classification results of delay cause and each delay cause is expressed as ID (ID of delay cause)-Rank (Mean score rank of delay cause)-Percentage (Percentage of response of delay type).

For excusable delay, 12 delay causes are classified as excusable delay for both owner and contractor. These delays are excusable when it occurs. Only DC14 and DC20 are non-excusable delay. Delays due to poor project planning and scheduling (DC14) and late procurement orders of material/equipment (DC20) are contractors' negligence that could be managed during project implementation. The owner and contractor showed no difference in perceived delay type that the delay cause is excusable or not in the Nigerian power project. Excusable delays are recognized as a reasonable delay cause to extend the schedule for both owner and contractor. In other words, the contractor is not negligible for delay. Thus, owners should be concentrated on managing those delay causes and appropriately allocate the responsibility of excusable delay.

For compensable delay, both owner and contractor responded that they don't know whether the 14 delay causes are compensable or not. This result is due to the background of the respondent. The compensation of damage from delay is usually defined through the contract. Since most of the respondents who are manager, engineer, and technician do not have much knowledge of a contract that requires expertise in law, the response that they don't know was dominant. Even though compensable delays are responsible for the owner, it is problematic that owners did not recognize or perceive the compensable delay.

For critical delay, both the owner and contractor perceived that DC5, DC9, and DC34 are a critical delay cause. The owner and contractor showed the difference in the criticality of some delay causes perceived. In association with difference, six delay causes (DC3, DC18, DC33, DC35, DC36) are differently perceived between owner and contractor. The 
owner responded that corruption and bureaucracy in government (DC36) is a critical delay cause, whereas the contractor responded that I don't know about DC36. The contractor perceived that design changes and delay in approving the changes (DC3) and government interference (DC33) are critical, whereas the owner responded that I don't know. This result indicated that the owner and contractor showed different viewpoints of criticality following their interest. This kind of difference can lead to disputes and delays. When the contractor claims the change order for these delay causes, the amount of time extension and compensation of both sides is contentious due to the difference in criticality perceived. Critical delays with high rank are properly managed for project delay performance. Among them, owners should concentrate on the excusable and compensable delays, and contractors should concentrate on the non-excusable delays.

For concurrent delay, the contractor perceived that all the delay causes are concurrent, while the owner perceived that several delay causes (DC18, DC34, DC35) are nonconcurrent. Though these delay causes are excusable for both owner and contractor, the contractor cannot receive the satisfiable change order from the owner, due to the difference of perceived delay type of cause for price fluctuation/inflation (DC18), cost of material (DC34), economic instability (DC35). In this kind of situation, as from the difference of delay impact analysis of owner and contractor, the dispute may occur.

Table 5. Types of delay cause of owner and contractor.

\begin{tabular}{|c|c|c|c|}
\hline \multicolumn{2}{|c|}{ Delay Types } & \multirow{2}{*}{$\begin{array}{c}\text { Owner } \\
\text { DC1-R2-90, DC2-R12-100, DC3-R6-86, } \\
\text { DC5-R4-95, DC9-R9-100, DC18-R3-61, } \\
\text { DC19-R8-77, DC32-R14-100, DC33-R7-100, } \\
\text { DC34-R10-75, DC35-R5-60, DC36-R1-98 } \\
\text { DC14-R11-93, DC20-R13-100 }\end{array}$} & \multirow{2}{*}{$\begin{array}{c}\text { Contractor } \\
\text { DC1-R-852, DC2-R12-67, DC3-R6-100, } \\
\text { DC5-R4-100, DC9-R9-100, DC18-R3-63, } \\
\text { DC19-R8-75, DC32-R14-80, DC33-R7-100, } \\
\text { DC34-R10-100, DC35-R5-100, DC36-R1-83 } \\
\text { DC14-R11-100 }\end{array}$} \\
\hline $\begin{array}{l}\text { Excusable } \\
\text { delay }\end{array}$ & $\begin{array}{l}\text { Excusable } \\
\text { Non-excusable } \\
\text { IDK }\end{array}$ & & \\
\hline $\begin{array}{c}\text { Compensable } \\
\text { delay }\end{array}$ & $\begin{array}{c}\text { Compensable } \\
\text { Non-compensable }\end{array}$ & $\begin{array}{l}\text { DC1-R2-100, DC2-R12-100, DC3-R6-80, } \\
\text { DC5-R4-100, DC9-R9-100, DC14-R11-100, } \\
\text { DC18-R3-72, DC19-R8-100, DC20-R13-100, } \\
\text { DC32-R14-100, DC33-R7-88, } \\
\text { DC35-R5-100, DC36-R1-100 }\end{array}$ & $\begin{array}{c}\text { DC1-R2-86, DC2-R12-78, DC3-R6-100, } \\
\text { DC5-R4-100, DC9-R9-100, DC14-R11-100, } \\
\text { DC18-R3-87, DC19-R8-75, DC32-R14-100, } \\
\text { DC33-R7-100, DC34-R10-67, } \\
\text { DC35-R5-100, DC36-R1-100 }\end{array}$ \\
\hline $\begin{array}{l}\text { Critical } \\
\text { Delay }\end{array}$ & $\begin{array}{c}\text { Critical } \\
\text { Non-critical }\end{array}$ & $\begin{array}{c}\text { DC5-R4-67, DC9-R9-67, } \\
\text { DC34-R10-50, DC36-R1-40 } \\
\text { DC14-R11-86, DC20-R13-50 } \\
\text { DC1-R2-42, DC2-R12-60, DC3-R6-78, } \\
\text { DC18-R3-61, DC19-R8-69, DC32-R14-100, } \\
\text { DC33-R7-75, DC35-R5-100 }\end{array}$ & $\begin{array}{c}\text { DC3-R6-50, DC5-R4-57, DC9-R9-50, } \\
\text { DC33-R7-80, DC34-R10-67 } \\
\text { DC14-R11-60, DC18-R3-50, DC35-R5-100 } \\
\text { DC1-R2-71, DC2-R12-44, DC19-R8-50, } \\
\text { DC32-R14-60, DC36-R1-50 }\end{array}$ \\
\hline \multirow[t]{2}{*}{$\begin{array}{l}\text { Concurrent } \\
\text { Delay }\end{array}$} & Concurrent & $\begin{array}{l}\text { DC1-R2-83, DC2-R12-100, DC3-R6-100, } \\
\text { DC5-R4-82, DC9-R9-89, DC14-R11-57, } \\
\text { DC19-R8-54, DC20-R13-50, DC32-R14-67, } \\
\text { DC33-R7-100, DC34-R10-50, DC36-R1-70 }\end{array}$ & \multirow[t]{2}{*}{$\begin{array}{c}\text { DC1-R2-71, DC2-R12-78, DC3-R6-100, } \\
\text { DC5-R4-86, DC9-R9-100, DC14-R11-100, } \\
\text { DC18-R3-50, DC19-R8-75, DC32-R14-80, } \\
\text { DC33-R7-100, DC34-R10-83, } \\
\text { DC35-R5-100, DC36-R1-83 }\end{array}$} \\
\hline & $\begin{array}{l}\text { Non-concurrent } \\
\text { IDK }\end{array}$ & DC18-R3-34, DC34-R10-50, DC35-R5-50 & \\
\hline
\end{tabular}

\section{Conclusions}

Identifying delay causes and impacts, and understanding the delay types perceived by both owners and contractors are crucial to achieving better project management performance. This study identified 39 delay factors through the literature review and collected the empirical opinions from 84 experts who had experience in power transmission and distribution projects. The delay causes are ranked and identified: 14 important delay causes in the Nigerian power project. In addition, this study classified the delay causes into four types (excusable, compensable, critical, and concurrent) depending on the perspective of the owner and contractor. 
This study proposed the 14 critical delay cause in Nigerian power construction projects as: Corruption and bureaucracy in government (DC36), Inadequate fund/budget allocation (DC1), Price fluctuation/inflation (DC18), Regulatory/license requirement (DC5), Economic instability (DC35), design changes and delay in approving the changes (DC3), Government interference (DC33), lack of cost and monitoring planning (DC19), Inappropriate project scope (DC9), Cost of material (DC34), Poor project planning and scheduling (DC14), Poor communication (DC2), Late procurement orders of material/equipment(DC20), and Political instability (DC32), ranked in ascending order.

Further, this study discussed the delay type classification from the perspective of the owner and contractor. The owner and contractor do not show the difference in classifying the 14 delay causes into excusable and compensable delays; whereas, for the critical delay, six delay causes (DC3, DC18, DC33, DC35, DC36) are differently perceived between owner and contractor. For concurrent delay, the contractor perceived that all the delay causes are concurrent, while the owner perceived that several delay causes (DC18, DC34, DC35) are non-concurrent.

In conclusion, results of this study provide some insight for a better understanding of the delay causes in the timely completion of Nigerian power projects for future reference. This study will help owners, contractors, and other players in power projects devise a means to assign levels to the delays and their types to allocate responsibilities (entitlement or claim) to the owners and contractors to achieve better performance of the project. However, delay causes and types can be different depending on project and country conditions. Thus, this study cannot be fully generalized to all projects. Readers are recommended to use these results and discussions as a reference.

Author Contributions: Conceptualization, U.I. and W.J.; Data curation, U.I.; Formal analysis, U.I., W.J. and C.Y.P.; Funding acquisition, W.J.; Investigation, U.I.; Methodology, U.I., W.J. and C.Y.P.; Supervision, W.J.; Writing—original draft, U.I.; Writing—review \& editing, W.J. and C.Y.P. All authors have read and agreed to the published version of the manuscript.

Funding: This research was supported by the 2021 research fund of the KEPCO International Nuclear graduate School (KINGS), Republic of Korea and supported by the Basic Science Research Program through the National Research Foundation of Korea (NRF) funded by the Ministry of Education (No. NRF-2020R1A2C1012739).

Data Availability Statement: The data presented in this study are available on request from the corresponding author.

Conflicts of Interest: The authors declare no conflict of interest.

\section{Appendix A}

\section{QUESTIONNAIRE CAUSES AND ASSOCIATED TYPES OF DELAYS IN NIGERIAN POWER PROJECTS}

Dear Sir/Madam,

A research project concerned with causes and associated types of delays in Nigerian power projects is currently being undertaken. As a stakeholder in development of power projects in Nigeria, your views and contribution to this research will be highly appreciated. Please respond to the questions freely and by ticking, numbering or explaining your views on the asked questions.

All information to be provided will be classified as highly confidential and will only be used for academic purposes only. Thank you very much for your anticipated cooperation.

\section{A. GENERAL INFORMATION}

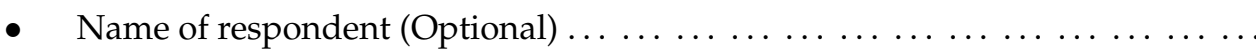

- Name of organization (Optional) $\ldots \ldots \ldots \ldots \ldots \ldots \ldots \ldots \ldots \ldots \ldots$

1. How can you group yourself? 

(a) Project owner
(b) Project contractor
(c) Others

2. What is your position as per your group selection?
(a) Project Manager
(b) Site manager
(c) Surveyor
(d) Engineer
(e) Technician
(f) Scheduler
(g) Consultant
(h) Others

3. For how many years have you practiced in the power industry?
(a) 0-5 Years
(b) 6-10years
(c) 11-15years
(d) Above 15 years: Outline some of them $\ldots \ldots \ldots \ldots \ldots$

\section{B. RESPONDENTS' EXPERIENCED PROJECT}

Please select one project that you fully experienced. Then, answer the followings:

4. Please, select one among the followings.
(a) Power Generation Project
(b) Transmission Project
(c) Distribution Project
(d) Others (mention)

5. Please select the original contract duration of your own experienced project
(a) Less than 1 year
(b) 1-2 Years
(c) 2-3 Year
(d) 3-4 Years
(e) More than 4 Years

6. Please select the original contract price of your experienced project
(a) Less than $\$ 10$ million
(b) \$10-50 million
(c) \$50-100 million
(d) \$100-500 million
(e) Above $\$ 500$ million

7. Who was in charge of design or engineering?
(a) Owner-side
(b) Contractor-side
(c) Other (Please, specify)

8. Please select the funding source
(a) The Central Government of Nigeria or Public institution
(b) Private company or commercial bank
(c) Multilateral development bank (Africa Development Bank, World Bank, etc.)
(d) Mix of $a$ and $b$
(e) Mix of a and c

9. What is the actual project completion time?
(a) About $0 \%$ increase of original contract duration
(b) About 5\% increase of original contract duration
(c) About $10 \%$ increase of original contract duration 
(d) About 20\% increase of original contract duration

(e) About 30\% increase of original contract duration

(f) About 50\% increase of original contract duration

(g) More than 50\% increase of original contract duration

10. What is the actual cost overrun?

(a) About $0 \%$ increase of original contract cost

(b) About 5\% increase of original contract cost

(c) About $10 \%$ increase of original contract cost

(d) About $20 \%$ increase of original contract cost

(e) About $30 \%$ increase of original contract cost

(f) About $50 \%$ increase of original contract cost

(g) More than $50 \%$ increase of original contract cost

\section{CAUSES OF DELAY}

Please identify which among the following factors are the causes of Project delay based on your project experience. Please tick $(\sqrt{ })$ against numbers showing the intensity of its contribution in the delay: 1 = No impact, 2 = Very Low (less than 1 week), 3 = Low (less than 2 weeks), 4 = Slightly low (less than 1 month), 5 = Slightly High (less than 3 months), 6 = High (less than 6 months), 7 = Very High (more than 6 months).

\begin{tabular}{|c|c|c|c|c|c|c|c|c|}
\hline \multirow[b]{2}{*}{ ID } & \multirow[b]{2}{*}{ Delay Causes } & \multicolumn{7}{|c|}{ Impact (Likert Scale) } \\
\hline & & $\begin{array}{c}1 \\
\text { (N/A) }\end{array}$ & $\begin{array}{c}2 \\
(1 W)\end{array}$ & $\begin{array}{c}3 \\
(2 W)\end{array}$ & $\begin{array}{c}4 \\
(1 \mathrm{M})\end{array}$ & $\begin{array}{c}5 \\
(3 \mathrm{M})\end{array}$ & $\begin{array}{c}6 \\
(6 \mathrm{M})\end{array}$ & $\begin{array}{c}7 \\
(6 \mathrm{M}>)\end{array}$ \\
\hline $\mathrm{DC} 1$ & Inadequate fund/budget allocation & & & & & & & \\
\hline DC2 & Poor communication & & & & & & & \\
\hline DC3 & Design changes, and delay in approving the changes & & & & & & & \\
\hline DC4 & Unrealistic contract duration/type & & & & & & & \\
\hline DC5 & Regulatory /license requirements & & & & & & & \\
\hline DC6 & Lack of experience of owner & & & & & & & \\
\hline DC7 & Delay in owner's procurement & & & & & & & \\
\hline DC8 & Poor management; coordination/supervision & & & & & & & \\
\hline DC9 & Inappropriate Project Scope & & & & & & & \\
\hline DC10 & Poor standard of drawing & & & & & & & \\
\hline DC11 & Inadequate design document review procedures & & & & & & & \\
\hline DC12 & Incomplete design and estimate at the time of tender & & & & & & & \\
\hline DC13 & Inappropriate data collection & & & & & & & \\
\hline DC14 & Poor project planning and scheduling & & & & & & & \\
\hline DC15 & Inadequate site supervision & & & & & & & \\
\hline DC16 & Strikes by site personnel & & & & & & & \\
\hline DC17 & Poor construction materials & & & & & & & \\
\hline DC18 & Price fluctuation/inflation & & & & & & & \\
\hline DC19 & Lack of cost and monitoring planning; poor cost control & & & & & & & \\
\hline DC20 & Late procurement orders of material/equipment & & & & & & & \\
\hline DC21 & Lack of experience of contractor & & & & & & & \\
\hline DC22 & Shortage of material in the market & & & & & & & \\
\hline DC23 & Equipment and tool shortage on site & & & & & & & \\
\hline DC24 & Shortage of manpower & & & & & & & \\
\hline
\end{tabular}




\begin{tabular}{lc}
\hline DC25 & High interest rates on mode of financing \\
\hline DC26 & Poor site working condition \\
\hline DC27 & Workers' absenteeism \\
\hline DC28 & Vandalism \\
\hline DC29 & Kidnapping, Terrorism \\
\hline DC30 & Theft \\
\hline DC31 & Conflicts with neighbor \\
\hline DC32 & Political instability \\
\hline DC33 & Government interference \\
\hline DC34 & Cost of material \\
\hline DC35 & Economic instability \\
\hline DC36 & Corruption, and bureaucracy in government \\
\hline DC37 & Natural disaster \\
\hline DC38 & Unexpected geological conditions \\
\hline DC39 & Act of God \\
\hline
\end{tabular}

\section{DELAY TYPES OF TOP FIVE DELAY CAUSES:}

1. a. Please, select the 1st ranked delay cause in Section $C$

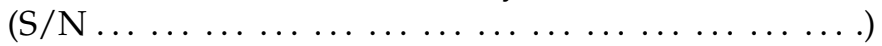

1. b. What is the delay type of this 1st ranked cause? (It's possible to answer more than one), Please tick $(\sqrt{ })$

i. Excusable delay: Occurs due to events which are outside the control of contractor.

ii. Non-excusable delay: Are such delay that no excuse can be given for them. They arise due to carelessness or actions and inactions of contractors and subcontractors.

iii. Concurrent delay: Contains two or more excusable delays that results in time extension distributed between owner and contractor.

iv. Non-concurrent delay: Contains two or more non-excusable delays which does not result in time extension.

v. Compensable delay: Are those in which contractor is entitled for extra compensation i.e., monetary and time extension as well.

vi. Non-compensable delay: Are such where both contractor and client are not responsible for delay. Under such circumstances only time extensions are granted and no monetary compensation is provided. Such delays include act of God

vii. Critical delay: Are those which cause delay to entire project completion date.

viii. Non-critical: Are delays that do not necessarily affect the project completion date but affects progress.

ix. I don't know exactly

2. a. Please, select 2 nd ranked delay cause in section $C$

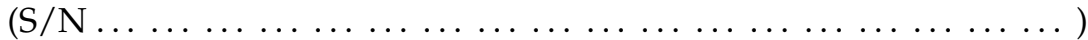

2. b. What is the delay type of this 2nd ranked cause? (It's possible to answer more than one), Please tick $(\sqrt{ })$

i. Excusable delay

ii. Non-excusable delay

iii. Concurrent delay

iv. Non-concurrent delay

v. Compensable delay

vi. Non-compensable delay

vii. Critical delay

viii. Non-critical

ix. I don't know exactly

3. a. Please, select 3rd ranked delay cause in Section C 


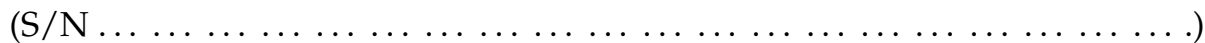

3. b. What is the delay type of this 3rd ranked cause? (It's possible to answer more than one). Please tick $(\sqrt{ })$
i. Excusable delay
ii. Non-excusable delay
iii. Concurrent delay
iv. Non-concurrent delay
v. Compensable delay
vi. Non-compensable delay
vii. Critical delay
viii. Non-critical
ix. I don't know exactly

4. a. Please, select 4 th ranked delay cause in Section C

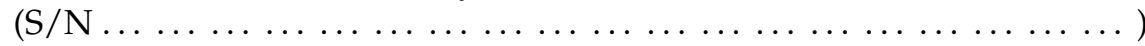

4. b. What is the delay type of this 4 th ranked cause? (It's possible to answer more than one). Please tick $(\sqrt{ })$
i. Excusable delay
ii. Non-excusable delay
iii. Concurrent delay
iv. Non-concurrent delay
v. Compensable delay
vi. Non-compensable delay
vii. Critical delay
viii. Non-critical
ix. I don't know exactly

5. a. Please, select 5 th ranked delay cause in Section $C$

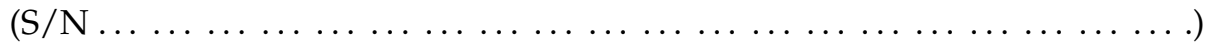

5. b. What is the delay type of this 5th ranked cause? (It's possible to answer more than one). Please tick $(\sqrt{ })$
i. Excusable delay
ii. Non-excusable delay
iii. Concurrent delay
iv. Non-concurrent delay
v. Compensable delay
vi. Non-compensable delay
vii. Critical delay
viii. Non-critical
ix. I don't know exactly

\section{References}

1. Project Management in Nuclear Power Plant Construction: Guidelines and Experience; Nuclear Energy Series; International Atomic Energy Agency: Vienna, Austria, 2012; ISBN 978-92-0-122210-7.

2. Ikechukwu, A.C.; Emoh, F.I.; Kelvin, O.A. Causes and Effects of Cost Overruns in Public Building Construction Projects Delivery, In Imo State, Nigeria. IOSR J. Bus. Manag. 2017, 19, 13-20. [CrossRef]

3. Gatugel Usman, Z.; Abbasoglu, S.; Tekbiyik Ersoy, N.; Fahrioglu, M. Transforming the Nigerian power sector for sustainable development. Energy Policy 2015, 87, 429-437. [CrossRef]

4. Vyas, S. Causes of Delay in Project Construction in Developing Countries. Indian J. Commer. Manag. Stud. 2013, IV, 24-29.

5. Long, N.D.; Ogunlana, S.; Quang, T.; Lam, K.C. Large construction projects in developing countries: A case study from Vietnam. Int. J. Proj. Manag. 2004, 22, 553-561. [CrossRef]

6. Banobi, E.T.; Jung, W. Causes and mitigation strategies of delay in power construction projects: Gaps between owners and contractors in successful and unsuccessful projects. Sustainability 2019, 11, 5973. [CrossRef]

7. Trauner, T.J. Construction Delays: Understanding Them Clearly, Analyzing Them Correctly; Butterworth-Heinemann: Oxford, UK, 2009; ISBN 0080957145. 
8. Pall, G.K.; Bridge, A.J.; Gray, J.; Skitmore, M. Causes of delay in power transmission projects: An empirical study. Energies 2019, 13, 17. [CrossRef]

9. Nundwe, M.; Mulenga, M.N. Delays in Construction of Electrical Power Transmission Lines in Zambia. Am. Sci. Res. J. Eng. Technol. Sci. 2017, 30, 82-96.

10. Mahamid, I.; Bruland, A.; Dmaidi, N. Causes of delay in road construction projects. J. Manag. Eng. 2012, 28, 300-310. [CrossRef]

11. Aziz, R.F.; Abdel-Hakam, A.A. Exploring delay causes of road construction projects in Egypt. Alex. Eng. J. 2016, 55, 1515-1539. [CrossRef]

12. Gebrehiwet, T.; Luo, H. Analysis of Delay Impact on Construction Project Based on RII and Correlation Coefficient: Empirical Study. Procedia Eng. 2017, 196, 366-374. [CrossRef]

13. Bajjou, M.S.; Chafi, A. Empirical study of schedule delay in Moroccan construction projects. Int. J. Constr. Manag. 2020, 20, 783-800. [CrossRef]

14. Rashid, Y. Analysis of delay factors and their effects on construction projects. Manag. Sci. Lett. 2020, 10, 1197-1204. [CrossRef]

15. Sagarkumar, R.P. Analysis for the Causes of Delay in Construction Projects. Int. J. Res. Appl. Sci. Eng. Technol. 2020, 8, 97-99. [CrossRef]

16. Hossen, M.M.; Kang, S.; Kim, J. Construction schedule delay risk assessment by using combined AHP-RII methodology for an international NPP project. Nucl. Eng. Technol. 2015, 47, 362-379. [CrossRef]

17. Idowu, A.; Tajudeen, O.I. Project Delivery Delay: The Nigeria Experience. IOSR J. Mech. Civ. Eng. 2016, 13, 84-87. [CrossRef]

18. Munvar, C.; Mengistu, D.G.; Mahesh, G. Concurrent Delay Analysis: Methods, Case Law, and Expert Perception. J. Leg. Aff. Disput. Resolut. Eng. Constr. 2020, 12, 04519035. [CrossRef]

19. Kasimu, A.M.; Isah, A.D. Causes of delay in Nigeria construction industry. Interdiscip. J. Contemp. Res. Bus. 2012, 4, 785-794.

20. Livengood, J. Knowns and Unknowns of Concurrent Delay. J. Leg. Aff. Disput. Resolut. Eng. Constr. 2017, 9, 06517002. [CrossRef]

21. Fakunle, F.F.; Fashina, A.A. Major delays in construction projects: A global overview. PM World J. 2020, IX, 1-15.

22. Hamzah, N.; Khoiry, M.A.; Arshad, I.; Tawil, N.M.; Che Ani, A.I. Cause of construction delay-Theoretical framework. Procedia Eng. 2011, 20, 490-495. [CrossRef]

23. Zaki, A.; Elalim, A.M.A.; Samadony, A.E.L. Factors Affecting Schedule Delay and Cost Overrun in Egyptian Construction Projects. In Proceedings of the 2nd International Conference Sustainable Construction and Project Management-Sustainable Infrastructure and Transportation for Future Cities, Aswan, Egypt, 16-18 December 2018; pp. 1-11.

24. Gajare, Y.; Attarde, P.; Parbat, D.K. Assessment of significant causes and effects of delays on the projects completion period. Int. J. Mod. Trends Eng. Res. 2015, 2, 88-93.

25. Jongo, J.S.; Tesha, D.N.G.A.K.; Kasonga, R.; Teyanga, J.J.; Lyimo, K.S. Mitigation Measures in Dealing with Delays and Cost Overrun in Public Building Projects in Dar-Es-Salaam, Tanzania. Int. J. Constr. Eng. Manag. 2019, 8, 81-96. [CrossRef] 